\title{
Ainda somos os mesmos, mas não vivemos como nossos pais: juventude e participação na Universidade de Brasília.
}

\author{
Patrícia Cabral de Arruda \\ Orientador: Prof. Dr. Mariza Veloso Motta Santos \\ Curso: Doutorado em Sociologia \\ Data da Defesa: 15.12.2012
}

E sta pesquisa concentra-se na juventude e seus temas. A primeira questão tratada é de cunho teórico-conceitual e revisita as discussões ao redor da categoria juventude. Muito cedo, os estudos trazem à tona a multiplicidade do conceito, com a utilização do termo no plural. Dessa maneira, a juventude, no contexto da universidade, vai se revelando um grupo ainda mais peculiar. Desde a escola de Chicago, passando pelos estudos sobre "geração" de Karl Mannheim, até chegar à ideia de geração "ioiô", apresentada por José Machado Pais, para referir-se às trajetórias de vida dos jovens na atualidade, a cada época, observam-se preocupações com as ações e estilos de vida juvenis. No caso específico do presente trabalho, essas preocupações aliam-se às que se relacionam com o contexto do ensino superior brasileiro e, mais especificamente com a história da Universidade de Brasília nessa conjuntura. Diante do exposto, essa pesquisa buscou indícios que levassem a encontrar, entre os estudantes da UnB, do campus Darcy Ribeiro, características e opiniões entre eles que permitissem sugerir respostas para questões como: os jovens atuais correspondem, de fato, aos adjetivos que os descrevem como desinteressados e/ou alienados? O trabalho de campo envolveu observação, questionários fechados voltados aos alunos do campus Darcy Ribeiro (Plano Piloto) e entrevistas com componentes de grupos que realizam, de algum modo, ações políticas na UnB. Os resultados apontam que cada forma de participação juvenil ou estudantil corresponde à época vivida. Assim, os jovens pesquisados podem ser considerados, em certa medida, uma imagem da sociedade em que vivem.

Palavras-chave: Juventude, Participação, Universidade, Cidade, Identidade. 